\title{
The Role of Financial Analysis in Assessing the Prices of Shares of Jordanian Industrial Joint Stock Companies Listed on the Amman Stock Exchange
}

\author{
Bahaa Sobhi AbdeLatif Awwad ${ }^{1} \&$ Ammar Zakaria Abdallh Salem ${ }^{2}$ \\ ${ }^{1}$ College of Economics and Business. Palestine Technical University - Kadoorie, Tulkrm, Palestine \\ ${ }^{2}$ College of Technical Palestine, Palestine Technical University - Kadoorie, Tulkrm, Palestine \\ Correspondence: Bahaa Sobhi AbdeLatif Awwad, College of Economics and Business. Palestine Technical \\ University - Kadoorie, Tulkrm, Palestine. Tel: 972-599-366-860. E-mail: dr.awwadb@ hotmail.com
}

Received: April 12, 2019

Accepted: May 15, 2019

Online Published: May 20, 2019

doi:10.5539/ijef.v11n6p12

URL: https://doi.org/10.5539/ijef.v11n6p120

\begin{abstract}
This study aimed to highlight the role of financial ratios in evaluating the prices of shares of Jordanian industrial joint stock companies listed on the Amman Stock Exchange; it also aimed to show which of these ratios has a more influential impact on these prices. The researcher conducted a test study survey to analyze the published data of (73) Jordanian industrial joint stock companies. The study sample $(\mathrm{n}=18)$ formed about $(25 \%)$ of the total population of the companies listed on the Amman Stock Exchange during the period 2010-2017. The researcher used the multiple regression method to identify the correlations between the financial ratios and the market share prices of the Jordanian industrial joint-stock companies. The results of the study showed a statistically significant effect for the Ratio of Circulation (CR), the Quick Ratio (QR), the Profit Per Share (EPS), the Return on Equity (ROE), the Debt Ratio (DR), the Total Assets Turnover (TAT), the Price- to- Earnings Ratio (PER), and the Price- to- Book Value Ratio (PBVR) on the market share price of the Jordanian industrial joint stock companies. However, the study showed no statistically significant effect of the Degree of Financial Leverage (DOL) and the rate of Working Capital Turnover (WCT) on the prices of these companies. In light of the study findings, the researcher recommended that all investors in the Amman Stock Exchange must have the know-how of the financial analysis, and to benefit from the expertise and knowledge of specialists in the financial analysis in order to rationalize their investment decisions and eventually take the best, decisive investment decisions. Companies should also consider the importance of financial leverage ratios and working capital turnover that may be reflected on the value/prices of their shares.
\end{abstract}

Keywords: Jordanian industrial joint stock companies, financial ratios, Amman stock exchange

\section{Introduction}

Financial analysis has emerged since the inception of the financial activity as an independent career. It is an important activity for the general management of the company because it is associated with the financial management that considers it as a tool to be used by several department that are closely linked to the company. Some of these parties are directly involved in the financial analysis including investors, lenders, governmental organizations, etc.

Financial analysis is one of the most important tools on which investors rely in making their decisions because it explains the elements of the financial statements and presents them in a way that is easy to understand. Financial analysis depends mainly on the financial statements which are the first accounting outputs that are, at the same time, one of the most important inputs of financial analysis. The financial analyst is required to confirm the validity of the accounting rules which are adopted in the preparation of financial statements. This is considered as the basic rule for the accuracy of the results of analysis. Nevertheless, the ability and experience of the financial analyst is of great importance and it plays a significant role in the preparation of high-quality financial analysis reports (Jerjawi, 2008, p. 3).

On the other hand, the financial ratios are among the most important financial analysis tools used by users of published financial statements, in general, and investors in the financial markets, in particular. It is employed in evaluating the performance of the companies that publish these data. The researchers aimed to analyze the role of 
these ratios in evaluating the prices of shares of the Jordanian industrial joint stock companies that are listed on the Amman Stock Exchange.

\subsection{Statement of the Problem}

The market prices of the shares of industrial companies listed on the Amman Stock Exchange (ASE) have been witnessing upwards and downward sharp fluctuations especially during the global financial crisis. These fluctuations are very likely to affect the nature of the investment decisions of its customers either by buying shares or selling them. According to the Efficient Market Hypothesis (EMH), information derived from the published financial statements of listed companies plays a role in determining the market price per share, particularly in semi-strong financial markets, which is the most common phenomenon in emerging economies such as the Jordanian. But the actual impact of this information for companies has raised and continues to raise a wide debate among experts and specialists in the financial markets. Consequently, many of them believe that the effect provided and stated within the (EMH) remains only in the context of theory rather than practice, because the decisions of dealers in the ASE are often based on non-scientific bases, but rather on the basis of leaks or rumors that are increasing in this field for two main reasons. First, absence of adequate transparency and disclosure; and second, the majority of these dealers or traders are speculators who risk their investment by making decisions based on what is known as the herd theory. They should have been guided by a set of financial indicators derived from the published financial statements (Hamdan, 2014, p. 145). Within this framework, the researchers sought to analyze the validity of this opinion by means of verifying whether the financial indicators (i.e., financial ratios) of a sample of the Jordanian public joint stock companies have an impact on the market prices of their shares or not. Therefore, the problem of the study can be clarified by the following question:

Is there a statistically significant effect of the financial ratios derived from the financial statements of the Jordanian industrial joint stock companies listed on the Amman Stock Exchange on the share prices? The researchers tried to find answers to the flowing sub-questions:

1). Is there a statistically significant effect of the liquidity ratios on the shares of the industrial joint stock companies listed on the ASE?

2). Is there a statistically significant effect of the profitability ratios on the shares of the industrial joint stock companies listed on the ASE?

3). Is there a statistically significant effect of the debt ratios on the shares of the industrial companies listed on the ASE?

4). Is there a statistically significant effect of the activity rates on the shares the industrial joint stock companies listed on the ASE?

5). Is there a statistically significant effect of the market rates on the shares of the industrial joint stock companies listed on the ASE?

\subsection{Importance of the Study and Its Objectives}

There is a number of factors that affect the investor when he/she tries to make an investment decision; the activity of the financial market of a given country indicates well the economic activity. Hence, this study emphasizes the importance of financial ratios and their role in the valuation of stock prices. Therefore, the results of this study are deemed significant as they will serve many categories of users of published financial data mainly current and other potential investors; it will also benefit lenders who rely on their decisions to assess the financial performance of companies that spread or circulate published financial statements. The study is also deemed significant as it tries to reveal the nature of the relationship between the financial ratios derived from the five types of financial statements and the prices of shares of industrial joint stock companies that are listed on the Amman Stock Exchange.

\section{Theoretical Background and Review of Literature}

\subsection{Theoretical Background}

This part of the study presents the role of financial ratios in the valuation of stock prices; it also reviews the most important literature including relevant studies of financial analysis and share prices assessment.

The role of financial ratios in evaluating the prices of shares of listed companies in the financial market:

Financial ratios are defined as "a financial analysis tool that is based on a set of logical relationships between two or more elements of the financial statements to form an opinion about the value of the company" (Pilbeam, 2007 , p. 188). In other words, financial ratios are useful tools that help companies and investors analyze and 
compare relationships between different pieces of financial information across an individual company's history, an industry, or an entire business sector.

According to the researchers, dealers in the financial market are interested in analyzing financial ratios including the following:

- Liquidity ratios: they are the ratios used by the management to judge the extent to which they are able to pay their accrued maturating obligations in the short-term. Through liquidity ratios, the lender is aware of the ability of an entity's management to pay off its short-term maturities and/or liabilities. If the management is unable to pay its obligations on due dates, this gives a negative indication to the investor. If the liquidity ratios are fairly high, it gives a positive indication to the investor, Consequently, the investor can take his/her investment decision to sell, buy or hold the stock based on this premise (Gibson, 2011, p. 205).

- Profitability Ratios: The ratios that measure the efficiency of an operating entity. Profitability is the final result of a number of policies and decisions taken by the financial manager. The information obtained is also shown by the profitability ratios of the entity during the year ended. Profitability is also an indicator of business success. More importantly, it is the primary concern of all stakeholders such as: (creditors, investors, owners and management). The profitability of a company or an enterprise can affect the investor's decision to know whether the firm is earning enough to distribute part of it to shareholders. The investment decision is made accordingly (Abbas, 2002, p. 75).

- Debt Ratios: These are the ratios that give indicators of the financial position of the company or an enterprise over the long term, and thus show the ability of that company or enterprise to repay its debts and long-term liabilities (such as bonds and long-term loans). Consequently, it shows the amount of debt contribution to capital. Debt ratios can be calculated based on budget; therefore, it is then called financial leverage ratios. However, it is likely to be called coverage ratios based on some income statement data. The ability of the company to pay its debts and interest expenses is considered an important aspect from the point of view of the creditor or the financier, as well as the investor because after the payment of the company's debts and expenses, the dividends are distributed to the shareholders. Here, the size of the debt and the interest expenses can be determined through the debt ratios which, but its turn, can affect the investor's decision (Karajeh et al., 2002, p. 190).

- Performance or Activity Ratios: These are the ratios that measure the efficiency of the management in using its available resources; they are usually represented in the form of turnover rates such as: (Asset Turnover Rate, Inventory Turnover Rate, Receivables Turnover Rate, Working Capital Turnover Rate, etc.). Through activity ratios, it also possible to determine the efficiency of an enterprise in the utilization of its resources. As a result, the investor soon realizes whether the management of the company or even the enterprise is efficient in managing and exploiting the resources available to it. This gives the investor a good indicator about the management of the company or facility and thus affects his/her investment decision either to sell, purchase or keep his/her own shares (Al-Dori \& Zinaad, 2003, p. 76).

- Market ratios: These are a set of financial ratios that show the relationship between the price of the share and earnings, cash flows and book value per share; these ratios also give investors a crystal-clear picture of the company's past and expected position. Market ratios are the most important financial ratios that investors who are active in the financial markets consider in making decisive decisions to buy or sell shares. They are also very significant the investor because they give him/her an indication of the company's past performance and future opportunities. The company's share movement in the stock exchange market is also very important from the point of view of shareholders and managements alike just like the Price-to-earnings ratio (PER). This ratio measures the amount that investors wish to pay for each JD of the company's profitability. This rate reflects investors' expectations regarding the company's future prospects. The market ratios are the most influential investment decision of the investor in the process of selling, buying or holding the stock. (Brigham \& Ehrhardt, 2005, p. 454).

\subsection{Relevant Previous Studies}

Analysis using the financial ratios method is one of the most widely used methods of disclosing the relationships between the items of the financial statements and the impact of these relationships on several factors including their impact or effect on the market prices of the shares of companies as shown in the current study as well as other studies. For example, UmIt and Khasawneh (2002) conducted a study that dealt with profit distribution policies adopted by the non-financial companies that are listed on the Amman Stock Exchange (Jordan Stock Market) using financial data during the period 1991-1998. The study results showed a strong relationship 
between dividends and stock prices. The researchers chose a sample of (26) Jordanian non-financial companies and used multiple regression to calculate the coefficients between dividends and stock. The researchers found significant relationship between the prices of shares and the distribution of dividends.

Another study conducted by Abu Hashish (2003) found the same results. The researcher concluded that the share price in the Jordanian Stock Market is directly related to Earnings per share and with net profit / equity, with the net profit / total assets, with the net profit / normal operating income, with the net cash flows / total assets, with the net profit / net profit realized, with the property rights / total sources of funds, with the ratio of trading and interest / total expenses, and with the market value / book value. However, the shares prices are inversely correlated with the fixed assets / total assets, with the total creditors / total sources of funds, and with the percentage of wages / total expenditure as well. The researcher also found that there is a significant relationship between five variables of the independent variables (including namely earnings per share, market value of shares / book value, equity / total sources of funds, Total Assets) and the price of the share in the Jordanian Stock Market using a correlation rate of (0.986).

Similarly, Sharab (2006) submitted a Master's Thesis at the University of Gaza and found a several results. Most importantly, the researcher found a statistically significant relationship between the following variables: earnings per share, date of announcement of cash dividend distribution, earnings per share in terms of cash profits, earnings per share in terms of retained earnings and the price of the share. The researcher also found that earnings per share affect the market price of the share, and that the effect of the share of cash dividends distributed is greater than the effect of the share of retained earnings on each of presentation and values of stock trading in the market. Finally, Sharab found that the earnings per share of the net profit exceeds the change in the market price of the share.

Furthermore, a study conducted by Sarkesian (2010) which aimed to reveal the factors determining the prices of shares of public joint stock companies listed on the Amman Stock Exchange and show which factors are more influential on these prices found that there is a significant correlation between the market price of industrial companies and the financial factors including (ROE, EVE, BVPS, DPS, and EPS). The researcher tried to build a model to predict these prices which can be used by the traders when taking decisive investment decisions in buying or selling. The study revealed several results, including a significant correlation between the market price of companies and the financial factors ROE, EVE, BVPS, DPS, EPS for industrial companies.

The study of Leggio et al. (2005) showed that capital stock returns in emerging markets are affected by a variety of factors other than those affecting stock returns in financial markets in developed countries. The researchers used artificial neural networks to predict stock price movements and thus the extent to which they can achieve capital gains resulting from the change in share prices. The researcher used stock return factor for a group of companies traded in the Shanghai Stock Exchange. The researcher concluded that the capital stock returns can predict the market prices of stocks and with a high degree of accuracy.

These studies coincided with the study of Naimy (2008), which aimed to study the relationship between stock prices and financial ratios, and compare the results for the Dubai and United States securities markets. It was noted that the relationship between stock prices in the Dubai stock market and their respective ratios is not significant, while a better correlation was observed with in the US stocks. Alerakis et al. (2010) confirmed such results when the researchers carried out a study that aimed at forecasting the returns of shares in the Athens Stock Exchange during the period 1993-2006. The researchers analyzed accounting information using financial ratios. The study findings revealed that analysis using financial ratios contains important information in predicting stock prices.

A number of studies were conducted in the same context. For instance, Al-tamimi et al (2011) found a strong and positive impact of the Profit Per Share (EPS) on share prices in the UAE; it also found a positive relation to Gross Domestic Profit. Moreover, Dima et al (2013) did a research study whose main premise was that the financial ratios reflect the financial health of the selected portfolio structure. This hypothesis was tested using a generalized method of moments (GMM) methodology. It was found that there was a long-term relationship even if there were some differences in stock responses European markets and the United States of America on financial information. Abadi et al. (2014) conducted a similar study; the results of the hypothesis test on the combined data showed that there is an important and direct relationship between the ratio of debt to total assets and stock prices while Menike Prabath (2014) dealt with the impact of Dividend Distributions per Share (DPS), Earnings per Share (EPS), and Book Value Per Share (BVPS) on a sample of 100 companies listed on the Columbia Stock Exchange (CSE) from 2008 to 2012. Using one model and multiple regression, the results revealed that EPS, DPS, and BVPS had a significant impact on stock price in (CSE). Shayeb and Ali (2006) 
carried out a study to determine the relationship between the performance of equity investment and the ratio of the market price of the share to the earnings per share theoretically and practically. Although capital market efficiency hypotheses reject the idea of extraordinary profits, the hypothesis of the ratio of market price per share to earnings per share has focused on predictability of the performance of these shares in the future, which is attributed to the amplification of investors' expectations. Therefore, the study supports the hypothesis of the importance of the ratio of the market price per share to the earnings per share in determining the performance of the portfolios, and this result does not support the hypothesis of efficiency of the financial market at the semi-strong level.

In a similar context, the study of (Najem, 2006) showed that investors in the Palestine market are aware of the importance of using accounting information in rationalizing their investment decisions; the researcher also found that the accounting information contained in the financial reports is sufficient and can be used in the investment decision, and that there are other types of information that are not provided in the financial statements and may affect the investment decision. The study proved that there are also some barriers and obstacles that limit the use of accounting information in rationalizing the investment decision. Similar findings were confirmed by Awad (2007) who reached a number of conclusions and a set of recommendations, including: (a) the importance of the commitment of the management when making their decisions to follow the principles of financial analysis by studying the financial statements of their economic units to obtain the indicators of financial analysis and then interpret these indicators in a way that serves the objectives of the decision makers, (b) the necessity of the internal beneficiary of the economic unit to exploit and employ the financial statements, accounting data, and the information available in these financial statements in rationalizing various administrative decisions. This can be done through the formation of appropriate administrative cadres for the purpose of conducting the financial analysis and understanding the meaning of financial analysis, what its objectives are, how to do it, and conducting training courses administered by specialized academic institutions. In this regard, the study of Mohammed (2014) reached a set of conclusions. For example, the researcher found no significant effect of the liquidity of the ordinary shares of the banking sector companies listed on the Iraqi Stock Exchange and Securities on its returns, but another study conducted by Mohammad and Adnan (2014) found that the liquidity of the Iraqi Market of Securities is escalating and is then followed by an increase in the returns of ordinary shares. The results of the statistical analysis indicated that there is a significant statistical effect of the liquidity of the Iraqi market for securities on the returns of ordinary shares. The most important recommendations were the need for the Iraq Stock Exchange to expand its activity in electronic trading.

\subsection{Contribution of the Current Study and How It Differs from Previous Studies}

This study was stemmed from the most recent studies that have been based on recent actual data of the industrial joint stock companies listed on the Amman Stock Exchange during the period (2010-2017). Most of the studies used five main categories of financial ratios method to evaluate the prices of shares of the industrial companies listed on the Amman Stock Exchange. However, most of the studies, that were available to the researcher, did not target the industrial sector alone; they and did not use all categories of financial ratios, either. Instead, they used a limited number of categories.

\section{Methodology of the Study}

The researchers of the current study used the analytical qualitative approach based on an empirical study technique of the actual financial statements which are published in the financial statements issued by the companies included in the study sample during the period 2010-2017.

\subsection{Study Community and Sample}

The study population ( $\mathrm{N}=73$ companies) consisted of all the Jordanian industrial joint stock companies which were listed on the Amman Stock Exchange of, while the sample (18 companies) was chosen randomly and represented $(25 \%)$ of the total number. This sample was selected from data released and published the financial statements issued by Amman Securities (Amman Stock Exchange) in the period in which this study was conducted, i.e., 31 December, 2017.

\subsection{Study Hypotheses}

The hypotheses of the study can be expressed as nihilistic as follows:

The main hypothesis:

H0: There is no statistically significant effect of the financial ratios derived from the financial statements of the Jordanian industrial joint stock companies listed on Amman Stock Exchange on the shares of these companies. 
The following sub-hypotheses or sub-assumptions were derived:

h01: There is no statistically significant effect of the liquidity ratios of the companies listed on Amman Stock Exchange on the shares of these companies.

h02: There is no statistically significant effect of the profitability ratios of the companies listed on Amman Stock Exchange on the shares of these companies.

h03: There is no statistically significant effect of the debt ratios of the companies listed on Amman Stock Exchange on the shares of these companies.

h04: There is no statistically significant effect of the activity ratios of the companies listed on Amman Stock Exchange on the shares of these companies.

h05: There is no statistically significant effect of the market ratios of the companies listed on Amman Stock Exchange on the shares of these companies.

3.3 Methods of Measuring the Study Variables According to (Gibson, 2011, p. 181)

1). Liquidity ratios:

Trading Ratio (CR): Current Assets / Current Liabilities

Quick ratios (QR): = Current Assets - Stock / Current Liabilities

2). Profitability Ratios:

Earnings per share (EPS): = Net profit / number of shares traded on

equity (ROE): = Net profit / total equity

3). Debt Ratios (DR):= Total Liabilities / Total Assets

Degree of Financial leverage (DOL): $=$ Profit before tax and interest $/$ profit

before tax

4). Activity ratios:

Total Asset Turnover $(\mathrm{TAT}):=$ Net Sales $/$ Total Asset Rate

Working capital turnover (WCT): = Net sales / working capital rate

5). Market ratios:

Price-to-Earnings Ratio (PER):= Market price / earnings per share

PBVR $=$ Market Price $/$ Book Value Per Share

The market value of the shares of the sample companies was determined at the annual closing prices during the period (2010-2017).

\subsection{Data Analysis and Testing of Hypotheses}

3.4.1 The Descriptive Analysis of the Study Variables

In the descriptive analysis of each of the five categories of financial ratios used in the study, the researchers used the abbreviations shown in Table 1:

Table 1. Symbols used for financial ratios

\begin{tabular}{lll}
\hline Category & Ratio & Symbol \\
\hline Ratios of Liquidity & Current Ratio & CR \\
& Quick Liquidity Ratio & QR \\
Ratios of Profitability & Earnings per Share & EPS \\
& Revenue on Equity & ROE \\
Ratios of Debt & Debt Ratio & DR \\
& Degree of financial Leverage & DOL \\
Ratios of Activity & Total Assets Turnover & TAT \\
& Working Capital Turnover & WCT \\
Ratios of Market & Price -to- Earnings Ratio & PER \\
& Price- to- Book Value Ratio & PBVR \\
\hline
\end{tabular}


The mean of each financial ratio was calculated with reference to the financial statements of the companies included in the study and published covering the financial years (2010-2017). The mean of the market price of these companies was also determined and calculated. The results are shown in table 2.

The above table shows the arithmetic mean of the trading ratios of companies was $(m=3.714)$. This means that the majority of the companies studied did not rely on short term loans to finance their activities. This is also confirmed by the relatively high arithmetic mean of the liquidity ratio $(m=1,886)$. On the other hand, the mean for the return on equity of the companies under scrutiny was (-006) which means that most companies did not achieve returns for shareholders.

It can be also noted that the calculated mean of the Debt Ratios of the companies studied is (.321); it means that most of these companies depended on the financing of shareholders in most of their capital structure. While the arithmetic mean of the total assets turnover and the working capital turnover of these companies were (- .554) was (3.656) respectively indicating the effectiveness of corporate management in achieving sales using assets and working capital.

The mean for the Price - to - Earnings Ratios for these companies $(m=24.98)$ indicated that the shares of these companies are traded at 24 times more than their earnings. While the arithmetic mean of Price- to- Book Value Ratio (PBVR) $(\mathrm{m}=1.637)$ indicated that the book value of the companies under study is greater than (1), meaning that the investor in these companies is willing to pay more than the accounting book value per share.

Table 2. Means for ratios

\begin{tabular}{|c|c|c|c|c|c|c|c|c|c|c|c|c|}
\hline \multirow{2}{*}{ No. } & \multirow{2}{*}{$\begin{array}{l}\text { Number of } \\
\text { company in the } \\
\text { circulated data } \\
\end{array}$} & \multirow[t]{2}{*}{ Name of the Company } & \multicolumn{10}{|c|}{ Mean for each ratio } \\
\hline & & & $\mathrm{CR}$ & $\mathrm{QR}$ & MP & EPS & ROE & $\mathrm{DR}$ & DOL & TAT & WCT PER & PBV \\
\hline 1 & 4 & $\begin{array}{c}\text { PHILADELPHIA } \\
\text { PHARMACEEUTICALS }\end{array}$ & 1.910 & 1.170 & 0.790 & -.370 & -.153 & 0.322 & 0.810 & 0.390 & $1.560-6.82$ & 0.870 \\
\hline 2 & 8 & $\begin{array}{c}\text { THE ARAB PESTICIDES \& } \\
\text { VETERINARY DRUGS MFG. } \\
\text { CO. }\end{array}$ & 2.370 & 1.370 & 1.620 & 0.150 & 0.102 & 0.312 & 1.170 & 0.630 & 1.50010 .83 & 1.110 \\
\hline 3 & 12 & $\begin{array}{l}\text { JORDAN CHEMICAL } \\
\text { INDUSTRIES }\end{array}$ & 1.160 & 0.610 & 2.070 & 0.060 & 0.038 & 0.528 & 2.780 & 0.590 & -18.054 .61 & 1.210 \\
\hline 4 & 16 & $\begin{array}{c}\text { JORDAN INDUSTRIAL } \\
\text { RESOURCES }\end{array}$ & 16.36 & 5.880 & 0.330 & 0.030 & 0.032 & 0.179 & 1.520 & 0.470 & 1.2909 .680 & 0.300 \\
\hline 5 & 20 & Paper and Cardboard Industries & 0.670 & 0.370 & 0.580 & -.130 & -.138 & 0.578 & 1.600 & 0.360 & -2.452 .280 & 0.580 \\
\hline 6 & 24 & NUTRI DAR & 1.060 & 0.870 & 1.540 & -.360 & -.428 & 0.732 & 1.160 & 0.870 & 4.2809 .800 & 2.110 \\
\hline 7 & 28 & PUBLIC INVESTMENT & 3.560 & 2.220 & 2.820 & 0.220 & 0.022 & 0.085 & 1.000 & 0.440 & 1.96012 .97 & 1.200 \\
\hline 8 & 32 & $\begin{array}{c}\text { SINIORA FOOD INDUSTRIES } \\
\text { PLC }\end{array}$ & 1.010 & 0.610 & 3.300 & 0.100 & 0.076 & 0.557 & 2.750 & 0.720 & 52.1714 .59 & 2.430 \\
\hline 9 & 36 & $\begin{array}{c}\text { UNION TOBACCO \& } \\
\text { CIGARETTE INDUSTRIES }\end{array}$ & 1.230 & 0.730 & 2.280 & 0.100 & 0.042 & 0.433 & 0.900 & 0.700 & 8.3004 .160 & 1.160 \\
\hline 10 & 40 & $\begin{array}{l}\text { INTERNATIONAL SILICA } \\
\text { INDUSTRIES CO. }\end{array}$ & 8.680 & 4.340 & 3.420 & 0.020 & 0.014 & 0.050 & 1.000 & 0.340 & 0.91023 .49 & 3.210 \\
\hline 11 & 43 & $\begin{array}{c}\text { UNITED IRON \& STEEL } \\
\text { MANUFACTURING CO. P.L.C }\end{array}$ & 2.230 & 1.470 & 1.240 & 0.080 & 0.071 & 0.296 & 1.300 & 1.100 & 3.17025 .19 & 1.070 \\
\hline 12 & 47 & THE PUBLIC MINING Co. Ltd. & 6.560 & 4.680 & 5.500 & 0.180 & 0.097 & 0.117 & 1.000 & 0.580 & 0.88054 .87 & 2.930 \\
\hline 13 & 52 & THE ARAB POTASH & 4.130 & 3.850 & 44.70 & 2.640 & 0.700 & 0.154 & 1.009 & 0.560 & 1.55018 .01 & 4.020 \\
\hline 14 & 56 & $\begin{array}{l}\text { ARABIAN STEEL PIPES } \\
\text { MANUFACTURING }\end{array}$ & 3.660 & 1.100 & 2.450 & 3.660 & 0.124 & 0.203 & 1.040 & 0.670 & 1.36011 .74 & 1.440 \\
\hline 15 & 60 & $\begin{array}{c}\text { Al JANOUB FILTERS } \\
\text { MANUFACTURING CO. LTD. }\end{array}$ & 1.380 & 0.730 & 1.210 & -.270 & -.616 & 0.560 & 0.840 & 0.250 & $3.380-5.08$ & 2.170 \\
\hline 16 & 64 & UNITED CABLE INDUSTRIES & 4.690 & 1.240 & 0.590 & 0.010 & 0.006 & 0.278 & -1.500 & 0.420 & 1.42096 .16 & 1.660 \\
\hline 17 & 68 & ARAB WEAVERS UNION CO. & 3.140 & 1.660 & 2.130 & 0.020 & 0.018 & 0.166 & 1.000 & 0.490 & 1.550117 .1 & 1.590 \\
\hline 18 & 70 & $\begin{array}{l}\text { INTERNATIONAL CERAMIC } \\
\text { INDUSTRIAL Co. Ltd. }\end{array}$ & 3.050 & 1.050 & 0.400 & -.110 & -.123 & 0.220 & 0.890 & 0.390 & $1.010-3.91$ & 0.410 \\
\hline & & MEAN & 3.714 & 1.886 & 3.305 & 0.335 & -.006 & 0.321 & 1.126 & 0.554 & 3.65624 .98 & 1.637 \\
\hline
\end{tabular}




\subsubsection{Testing the Validity of Data for Statistical Analysis}

In order to verify the objectivity of the results of the study, the Kolmogorov-Smirnov test was carried out in order to verify that the study data were void of statistical problems that might adversely affect the results of the hypothesis test. In contrast, a false correlation is created between the independent and dependent variables of the study. Thus, the correlation loses its ability to explain or predict the phenomenon under study, as shown in Table 3.

Table 3. Normal distribution for study variables

\begin{tabular}{llcll}
\hline No. & Variable & Kolmogorov-Smirnov & Sig.* & Result \\
\hline 1 & Ratios of Liquidity & .6670 & .7660 & Follow the normal distribution \\
2 & Ratios of Profitability & .6610 & .7740 & Follow the normal distribution \\
3 & Ratios of Debt & .7000 & .7110 & Follow the normal distribution \\
4 & Ratios of Activity & .5640 & .9080 & Follow the normal distribution \\
5 & Ratios of Market & .8610 & .4490 & Follow the normal distribution \\
6 & Market Price per Share & .8060 & .5340 & Follow the normal distribution \\
\hline
\end{tabular}

\subsubsection{Testing Hypotheses}

The main hypothesis $\mathrm{H} 0$ states that:

H0: There is no statistically significant effect of the financial ratios derived from the financial statements of the Jordanian industrial joint stock companies listed on Amman Stock Exchange on the shares of these companies.

To test this hypothesis, multiple regression analysis was used to verify the effect of financial ratios (including: liquidity ratios, profitability ratios, debt ratios, activity ratios and market ratios) for Jordanian industrial joint stock companies listed on the Amman Stock Exchange on their share prices, as shown in Table 4.

Table 4. Results of the multiple regression analysis test for the effect of the financial ratios of the Jordanian industrial joint stock companies on the share prices

\begin{tabular}{|c|c|c|c|c|c|c|c|c|c|c|}
\hline & \multicolumn{2}{|c|}{ Model Summary } & \multicolumn{4}{|c|}{ One Way Analysis of Variance (ANOVA) } & \multicolumn{4}{|c|}{ Coefficients } \\
\hline $\begin{array}{c}\text { Dependent } \\
\text { Variable }\end{array}$ & $\mathrm{R}$ & $\mathrm{R}^{2}$ & DF & & $\mathrm{F}$ & Sig.* & $\begin{array}{l}\beta \text { Regression } \\
\text { for financi }\end{array}$ & $\begin{array}{l}\text { fficients } \\
\text { atios }\end{array}$ & $\mathrm{T}$ & Sig.* \\
\hline \multirow{5}{*}{$\begin{array}{c}\text { Prices of } \\
\text { the } \\
\text { Markets }\end{array}$} & \multirow{5}{*}{0.635} & \multirow{5}{*}{0.403} & Linear Regression & 5 & \multirow{5}{*}{27.8} & \multirow{5}{*}{0.00} & Liquidity & 0.399 & 4.762 & 0.000 \\
\hline & & & & & & & Profitability & 0.410 & 4.838 & 0.000 \\
\hline & & & $\mathrm{R}$ & 12 & & & Debt & 0.333 & 3.407 & 0.001 \\
\hline & & & & & & & Activity & 0.232 & 2.408 & 0.018 \\
\hline & & & Total & 17 & & & Market & 0.300 & 3.747 & 0.000 \\
\hline
\end{tabular}

* The effect is statistically significant at $(\alpha \geq 0.05)$; The value of the periodic $\mathrm{F}$ at $(\alpha \geq 0.05)=3.105$; T-value of the table at $(\alpha \geq 0.05)=$ 1.739 .

Table 4 shows the effect of the financial ratios used in the study hypotheses on the market prices of the Jordanian industrial joint stock companies listed on the Amman Stock Exchange. It reveals the following indicators:

1). The values of the sig * level associated with testing all these ratios together $(0.000)$ are less than the test reference value of (0.05). Therefore, the basic null hypothesis $(\mathrm{H} 0)$ is rejected and the alternative hypothesis $(\mathrm{Ha})$ is accepted, which means that together they affect the market prices of the shares of those companies.

2). The correlation coefficient $\mathrm{R}(0.635)$, which is relatively high, indicates that the relationship between these ratios at the market prices of shares is relatively strong to the extent that the coefficient of determination (R2) which is $(0.403)$ indicates that approximately $40 \%$ of the fluctuations determined in prices Stocks are caused by fluctuations in these ratios.

3). The figures shown in the table for each category separately refer indicate the following:

- the five categories of ratios separately affect the market prices of shares.

- the differences in the regression coefficient $(\beta)$ among them indicate that this effect varies among the various categories of ratios. Profitability ratios are ranked first in strength of influence, while activity ratios are ranked last. 
These findings can be explained, according to the researchers, by saying that traders on the ASE are paying more attention to corporate profitability at the expense of other indicators.

h01: There is no statistically significant effect of the liquidity ratios of the companies listed on Amman Stock Exchange on the shares of these companies.

To test this hypothesis, a multiple regression analysis was used to verify the effect of the Liquidity Ratios (CR and QR); the results obtained are shown in Table 5.

Table 5. Results of the multiple regression analysis test for the effect of the liquidity ratios of the Jordanian industrial joint stock companies on the share prices

\begin{tabular}{|c|c|c|c|c|c|c|c|c|c|c|}
\hline & \multicolumn{2}{|c|}{ Model Summary } & \multicolumn{4}{|c|}{ One Way Analysis of Variance (ANOVA) } & \multicolumn{4}{|c|}{ Coefficients } \\
\hline $\begin{array}{c}\text { Dependent } \\
\text { Variable }\end{array}$ & $\mathrm{R}$ & $\mathrm{R}^{2}$ & $\mathrm{DF}$ & & F & Sig.* & $\begin{array}{r}\beta \text { Regressi } \\
\text { fina }\end{array}$ & $\begin{array}{l}\text { ficients for } \\
\text { tios }\end{array}$ & $\mathrm{T}$ & Sig.* \\
\hline \multirow{2}{*}{$\begin{array}{l}\text { Prices of } \\
\text { the }\end{array}$} & \multirow{3}{*}{0.559} & \multirow{3}{*}{0.313} & Linear Regression & 2 & \multirow{3}{*}{6.194} & \multirow{3}{*}{0.025} & \multirow{2}{*}{ (CR) } & \multirow{2}{*}{0.267} & \multirow{2}{*}{3.532} & \multirow{2}{*}{0.031} \\
\hline & & & Residuals & 15 & & & & & & \\
\hline Markets & & & Total & 17 & & & $(\mathrm{QR})$ & 0.214 & 3.445 & .0430 \\
\hline
\end{tabular}

* The effect is statistically significant at $(\alpha \geq 0.05)$; The value of the periodic $\mathrm{F}$ at $(\alpha \geq 0.05)=3.105$; T-value of the table at $(\alpha \geq 0.05)=$ 1.739; CR: Current Ratios; QR: Quick Ratios.

The data in Table 5 indicate the following:

1). The value of the sig* associated with both (CR, QR) which is 0.025 is less than 0.05 . Therefore, the first sub-hypothesis (H01) should be rejected; this means that liquidity ratios have a significant impact on the market price of shares.

The correlation coefficient $(\mathrm{R}=0.559)$ indicates a relatively reasonable correlation between them, to the extent that about (31\%) of the fluctuations in stock prices can be explained by the fluctuations in the liquidity ratios.

2). On the other hand, when each of the two ratios is taken individually, the difference of the regression coefficients $(\beta)$ for each $(0.267)$ and $(0.214)$ respectively indicates that (CR) has a higher effect than the other (QR) although both affect the prices. Consequently, the researchers reject the sub-hypothesis (H01).

H02: There is no statistically significant effect of the profitability ratios of the companies listed on Amman Stock Exchange on the shares of these companies.

To test this hypothesis, a multiple regression analysis was used to verify the effect of the Profitability Ratios (ROE and EPS); the results obtained are shown in Table 1.6.

Table 6. Results of the multiple regression analysis test for the effect of the profitability ratios of the Jordanian industrial joint stock companies on the share prices

\begin{tabular}{|c|c|c|c|c|c|c|c|c|c|c|}
\hline \multirow[b]{2}{*}{$\begin{array}{c}\text { Dependent } \\
\text { Variable }\end{array}$} & \multicolumn{2}{|c|}{ Model Summary } & \multicolumn{4}{|c|}{ One Way Analysis of Variance (ANOVA) } & \multicolumn{4}{|c|}{ Coefficients } \\
\hline & $\mathrm{R}$ & $\mathrm{R}^{2}$ & DF & & $\mathrm{F}$ & Sig.* & $\begin{array}{r}\beta \text { Regression } \\
\text { for financ }\end{array}$ & $\begin{array}{l}\text { cients } \\
\text { os }\end{array}$ & $\mathrm{T}$ & Sig.* \\
\hline Prices of & \multirow{3}{*}{0.726} & \multirow{3}{*}{0.528} & Linear Regression & 2 & \multirow{3}{*}{8.374} & \multirow{3}{*}{0.004} & \multirow{2}{*}{ (ROE) } & \multirow{2}{*}{0.319} & \multirow{2}{*}{2.188} & \multirow{2}{*}{0.03} \\
\hline the & & & Residuals & 15 & & & & & & \\
\hline Markets & & & Total & 17 & & & (EPS) & 0.573 & 2.583 & 0.021 \\
\hline
\end{tabular}

* The effect is statistically significant at $(\alpha \geq 0.05)$; The value of the periodic $\mathrm{F}$ at $(\alpha \geq 0.05)=3.105$; T-value of the table at $(\alpha \geq 0.05)=$ 1.739; ROE: Return on Equity; EPS: Earnings Per Share.

The data in Table 6 indicate the following:

1). The value of the sig* associated with both (EPS, ROE) which is 0.004 is less than 0.05 . Therefore, the first sub-hypothesis (H02) should be rejected; this means that profitability ratios have a significant impact on the market price of shares.

The correlation coefficient $(\mathrm{R}=0.559)$ indicates a relatively high correlation between them, to the extent that about $(52 \%)$ of the fluctuations in stock prices can be explained by the fluctuations in the profitability ratios.

2 ). On the other hand, when each of the two ratios is taken individually, the difference of the regression coefficients $(\beta)$ for each $(0.573)$ and (0.319) respectively indicates that (EPS) has a higher effect than the other (ROE) although both affect the prices. 
H03: There is no statistically significant effect of the debt ratios of the companies listed on Amman Stock Exchange on the shares of these companies.

To test this hypothesis, a multiple regression analysis was used to verify the effect of the Debt Ratios (DR and DOL); the results obtained are shown in Table 7.

Table 7. Results of the multiple regression analysis test for the effect of the debt ratios of the Jordanian industrial joint stock companies on the share prices

\begin{tabular}{|c|c|c|c|c|c|c|c|c|c|c|}
\hline & \multicolumn{2}{|c|}{ Model Summary } & \multicolumn{4}{|c|}{ One Way Analysis of Variance (ANOVA) } & \multicolumn{4}{|c|}{ Coefficients } \\
\hline $\begin{array}{c}\text { Dependent } \\
\text { Variable }\end{array}$ & $\mathrm{R}$ & $\mathrm{R}^{2}$ & $\mathrm{DF}$ & & $\mathrm{F}$ & Sig.* & $\begin{array}{r}\beta \text { Regression } \\
\text { for finan }\end{array}$ & $\begin{array}{l}\text { ficients } \\
\text { tios }\end{array}$ & $\mathrm{T}$ & Sig.* \\
\hline \multirow{2}{*}{$\begin{array}{c}\text { Prices of } \\
\text { the }\end{array}$} & \multirow{3}{*}{0.456} & \multirow{3}{*}{0.207} & Linear Regression & 2 & \multirow{3}{*}{6.524} & \multirow{3}{*}{0.033} & \multirow{2}{*}{ (DR) } & \multirow{2}{*}{0.271} & \multirow{2}{*}{3.024} & \multirow{2}{*}{0.022} \\
\hline & & & Residuals & 15 & & & & & & \\
\hline Markets & & & Total & 17 & & & (DOL) & 0.078 & 0.328 & 0.748 \\
\hline
\end{tabular}

* The effect is statistically significant at $(\alpha \geq 0.05) ; *$ The value of the periodic $\mathrm{F}$ at $(\alpha \geq 0.05)=3.105 ; *$ T-value of the table at $(\alpha \geq 0.05)=$ 1.739 ; *ROE: Debt Ratios; *EPS: Degree of financial Leverage.

The data in Table 7 indicate the following:

1). The value of the sig* associated with both (DR, DOL) which is 0.033 is less than 0.05 . Therefore, the first sub-hypothesis (H03) should be rejected; this means that profitability ratios have a significant impact on the market price of shares.

The correlation coefficient $(\mathrm{R}=0.559)$ indicates a relatively reasonable correlation between them, to the extent that about $(20 \%)$ of the fluctuations in stock prices can be explained by the fluctuations in the profitability ratios.

$2)$. On the other hand, when each of the two ratios is taken individually, the difference of the regression coefficients $(\beta)$ for each $(0.072)$ and (0.078) respectively indicates that (DR) affects the prices while the (DOL) do not.

H04: There is no statistically significant effect of the Activity Ratios of the companies listed on Amman Stock Exchange on the shares of these companies.

To test this hypothesis, a multiple regression analysis was used to verify the effect of the Activity Ratios (TAT and WCT); the results obtained are shown in Table 8.

Table 8. Results of the multiple regression analysis test for the effect of the activity ratios of the Jordanian industrial joint stock companies on the share prices

\begin{tabular}{|c|c|c|c|c|c|c|c|c|c|c|}
\hline & \multicolumn{2}{|c|}{ Model Summary } & \multicolumn{4}{|c|}{ One Way Analysis of Variance (ANOVA) } & \multicolumn{4}{|c|}{ Coefficients } \\
\hline $\begin{array}{c}\text { Dependent } \\
\text { Variable }\end{array}$ & $\mathrm{R}$ & $\mathrm{R}^{2}$ & DF & & $\mathrm{F}$ & Sig.* & $\begin{array}{l}\beta \text { Regression } \\
\text { for finan }\end{array}$ & $\begin{array}{l}\text { ficients } \\
\text { tios }\end{array}$ & $\mathrm{T}$ & Sig.* \\
\hline \multirow{2}{*}{$\begin{array}{c}\text { Prices of } \\
\text { the }\end{array}$} & \multirow{3}{*}{0.333} & \multirow{3}{*}{0.110} & Linear Regression & 2 & \multirow{3}{*}{5.118} & \multirow{3}{*}{0.029} & \multirow{2}{*}{$(\mathrm{TAT})$} & \multirow{2}{*}{0.333} & \multirow{2}{*}{3.123} & \multirow{2}{*}{0.004} \\
\hline & & & Residuals & 15 & & & & & & \\
\hline Markets & & & Total & 17 & & & (WCT) & 0.015 & 0.057 & 0.955 \\
\hline
\end{tabular}

* The effect is statistically significant at $(\alpha \geq 0.05)$; * The value of the periodic $\mathrm{F}$ at $(\alpha \geq 0.05)=3.105$; * T-value of the table at $(\alpha \geq 0.05)=$ 1.739; *TAT: Total Assets Turnover; *WCT: Working Capital Turnover.

The data in Table 8 indicate the following:

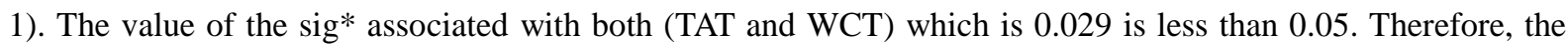
first sub-hypothesis (H04) should be rejected; this means that activity ratios have a significant impact on the market price of shares.

The correlation coefficient $(\mathrm{R}=0.559)$ indicates a relatively low correlation between them, to the extent that about $(1 \%)$ of the fluctuations in stock prices can be explained by the fluctuations in the activity ratios.

$2)$. On the other hand, when each of the two ratios is taken individually, the difference of the regression coefficients $(\beta)$ for each $(0.333)$ and $(0.150)$ respectively indicates that (TAT) affects the prices while the (WCT) do not.

H05: There is no statistically significant effect of the market ratios of the companies listed on Amman Stock Exchange on the shares of these companies. 
To test this hypothesis, a multiple regression analysis was used to verify the effect of the Market Ratios (PER and PBVR); the results obtained are shown in Table 9.

Table 9. Results of the multiple regression analysis test for the effect of the market ratios of the Jordanian industrial joint stock companies on the share prices

\begin{tabular}{|c|c|c|c|c|c|c|c|c|c|c|}
\hline & \multicolumn{2}{|c|}{ Model Summary } & \multicolumn{4}{|c|}{ One Way Analysis of Variance (ANOVA) } & \multicolumn{4}{|c|}{ Coefficients } \\
\hline $\begin{array}{c}\text { Dependent } \\
\text { Variable }\end{array}$ & $\mathrm{R}$ & $\mathrm{R}^{2}$ & $\mathrm{DF}$ & & $\mathrm{F}$ & Sig.* & $\begin{array}{r}\beta \text { Regression } \\
\text { for finan }\end{array}$ & $\begin{array}{l}\text { ficients } \\
\text { tios }\end{array}$ & $\mathrm{T}$ & Sig.* \\
\hline \multirow{2}{*}{$\begin{array}{c}\text { Prices of } \\
\text { the }\end{array}$} & \multirow{3}{*}{0.678} & \multirow{3}{*}{0.460} & Linear Regression & 2 & \multirow{3}{*}{6.378} & \multirow{3}{*}{0.010} & \multirow{2}{*}{ (PRS) } & \multirow{2}{*}{0.444} & \multirow{2}{*}{2.974} & \multirow{2}{*}{0.004} \\
\hline & & & Residuals & 15 & & & & & & \\
\hline Markets & & & Total & 17 & & & $(\mathrm{PBVR})$ & 0.688 & 3.659 & 0.003 \\
\hline
\end{tabular}

* The effect is statistically significant at $(\alpha \geq 0.05)$; The value of the periodic $\mathrm{F}$ at $(\alpha \geq 0.05)=3.105$; * T-value of the table at $(\alpha \geq 0.05)=$ 1.739; *PES: Price to Earnings Ratio; *PBVR: Price- to- Book Value Ratio.

The data in Table 9 indicate the following:

1). The value of the sig* associated with both (PER, PBVR) which is 0.010 is less than 0.05 . Therefore, the first sub-hypothesis (H02) should be rejected; this means that market ratios have a significant impact on the market price of shares.

The correlation coefficient $(\mathrm{R}=0.678)$ indicates a relatively high correlation between them, to the extent that about (46\%) of the fluctuations in stock prices can be explained by the fluctuations in the profitability ratios.

$2)$. On the other hand, when each of the two ratios is taken individually, the difference of the regression coefficients $(\beta)$ for each $(0.444)$ and $(0.688)$ respectively indicates that (PER) has a higher effect than the other (PBVR) although both affect the prices.

Table 10. A comparative table of the effect of individual categories of financial ratios on the market prices of the shares of the Jordanian industrial joint stock companies

\begin{tabular}{clcccc}
\hline No. & Categories & Sig* & R & $\mathbf{R}^{\mathbf{2}}$ & Rank \\
\hline $\mathbf{1}$ & Liquidity Ratios & 0.025 & 0.559 & 0.312 & 3 \\
$\mathbf{2}$ & Profitability ratios & 0.004 & 0.726 & 0.528 & 1 \\
$\mathbf{3}$ & Debt Ratios & 0.033 & 0.456 & 0.207 & 4 \\
$\mathbf{4}$ & Activity Ratios & 0.029 & 0.333 & 0.110 & 5 \\
$\mathbf{5}$ & Market Ratios & 0.010 & 0.678 & 0.460 & 2 \\
\hline
\end{tabular}

Table 11. A comparative table of the effect of the five categories of financial ratios on the market prices of the shares of the Jordanian industrial joint stock companies

\begin{tabular}{lcccc}
\hline No. & Categories & Sig* & B & Rank \\
\hline $\mathbf{1}$ & CR & 0.031 & 0.267 & 7 \\
$\mathbf{2}$ & QR & 0.043 & 0.214 & 8 \\
$\mathbf{3}$ & EPS & 0.039 & 0.319 & 5 \\
$\mathbf{4}$ & ROE & 0.021 & 0.573 & 2 \\
$\mathbf{5}$ & DR & 0.022 & 0.271 & 6 \\
$\mathbf{6}$ & DOL & 0.748 & 0.087 & 9 \\
$\mathbf{7}$ & TAT & 0.004 & 0.333 & 4 \\
$\mathbf{8}$ & WCT & 0.955 & 0.015 & 10 \\
$\mathbf{9}$ & PER & 0.004 & 0.444 & 3 \\
$\mathbf{1 0}$ & PBVR & 0.003 & 0.688 & 1 \\
\hline
\end{tabular}

\section{Discussion of Conclusions and Recommendations}

\subsection{Discussion of Results}

The results of the sub-hypotheses test $(\mathrm{H01}, \mathrm{H} 02, \mathrm{H} 03, \mathrm{H} 04, \mathrm{H} 05)$ indicate that all financial ratios have a statistically significant effect on the market prices of the shares of the public shareholding companies listed on the Amman Stock Exchange. However, the values of this effect vary according to the correlation coefficient (R) as well as the regression factor (R2). These ranks can be arranged according to the strength of their effect as 
follows: (profitability ratios, market ratios, liquidity ratios, debt ratios, and activity ratios).

With respect to the relative effect of each of these ratios individually, and when considering the data in Table 9, they can be summarized as follows:

a. The (Sig*) values associated with each ratio denotes the rejection of the sub- hypothesis (HO) for all ratios except for percentages (6 and 8 ) which must be accepted. This means that except for these two ratios, the rest of the ratios affect the market prices of the shares.

b. The values for the regression coefficient (B) indicate the varying effect of these ratios on stock prices. Priceto - Book Value Ratio is ranked first, followed by return on Equity (ROE); on the other hand, the Working Capital Turnover (WCT) is ranked ninth and the Financial Leverage Ratio is ranked tenth.

c. Looking at (B) values in table 1.11. above, it can be noticed that the results indicate that the profitability ratios (ROE and EPS) compared with market ratios (PER and PBVR) are the most influential among the financial ratios on market prices for the shares of the Jordanian industrial companies listed on the Amman Stock Exchange.

\subsection{Discussion of Recommendations}

Based on presented in the results obtained from the statistical analysis of the data, the researchers recommended the following:

1). All investors in the Amman Stock Exchange should have the know-how in the financial analysis, or should benefit from the expertise and knowledge of the specialists in financial analysis to rationalize their investment decisions.

2). the necessity to develop and improve the efficiency of the financial market to increase its medium level of efficiency to a higher level or even an elevated, high level.

3 ). The necessity of establishing or proposing appropriate mechanisms to follow up and monitor the performance of management of some companies to improve the financial ratios derived from their financial statements due to the fact that this may affect the credibility of these ratios.

4). The need to conduct other studies that test the role of financial ratios in assessing the prices of shares of Jordanian public joint stock companies in the rest of the sectors (including the non-industrial sector).

5). Carrying out other studies for the sake of determining the impact of non-financial factors on the prices of shares of public joint stock companies listed on the Amman Stock Exchange, such as: quality of management, reputation of the company, and more importantly, the leaks and rumors related to internal information that companies management deliberately spread to the financial market in order to affect prices of their shares especially when they leak fake and unreal information.

\section{References}

Abadi, H. R., Naoji, S. J. M., \& Rafat, B. (2014). The relationship between stock prices and debt ratio and Capital flows with assets. Interdisciplinary Journal of Contemporary Research In Business, 6(1), 140-146.

Abbas, A. (2002). Financial Management in Business Organizations. Amman, Jordan: Al-Raed Library.

Abu-Hashish, K. (2003). The Role of Accounting Information published in the Stock Market Forecasting in the Hashemite Kingdom of Jordan (Applied Study). Al-Busayer Journal, 7(2), 969-149.

Al-Dori, M., \& Zannad, N. (2003). Computer Financial Analysis. Amman: Dar Wael Publishing \& Publishing.

Alerakis, C., Patra, T., \& Poshakwate, S. (2010). Predictability of Stocks Returns Using Financial Statements Information Evidence on Semi -strong Efficiency of Emerging Greek Stock Market. Accounting \& Business Research, 20, 1321-1326. https://doi.org/10.1080/09603107.2010.482517

Al-tamimi, H. A., Alwan, A. A., \& Rahman, A. A. (2011). Factors Affecting Stock Prices in the UAE Financial markets. Accounting \& Business Research, 21,3-19. https://doi.org/10.1080/15475778.2011.549441

Awad, Q. S. (2007). The Impact of Financial Analysis Indicators in the Rationalization of Investment Decisions, Field Study in the General Company for Textile Industries. Al Qadissiya Journal of Administrative and Economic Sciences, 9.

Bodie, Z., Kane, A., \& Marcus, A. J. (2011). Investments and Portfolio Management (9th ed.). USA, New York.

Brigham, M., \& Eugene, F. C. (2005). Financial Management (11th ed.). USA

Dima, B., Dima, S. M., Samarat, O., \& Angyal, C. (2013). Financial ratio and stock price on developed capital 
markets. Economics Series, 23(1), 1-12.

Gibson, C. H. (2011). Financial Statement Analysis (12th ed.). New York: Tomson.

Gong, M. C., \& Firth, M. J. K. (2003). The Use of Accounting Information for the Valuation of Dul- Class Shares Listed on China's Stock-Market. Accounting \& Business Research, 32(3), 123-131. https://doi.org/10.1080/00014788.2002.9728963

Hamdan, S. H. (2014). Elements of the Modern Stock Market Building, Amman Financial Market Performance Study. PhD thesis from Al-Jinan University, Tripoli, Lebanon.

Jerjawi, H. (2008). The role of financial analysis of financial information published in the stock price forecasting lists (Unpublished master thesis). Islamic University, Gaza, Palestine.

Karajeh et al. (2002). Management and Management II. Oman Publishing House LTD.

Kieso, D. E., \& Weygandt. (2007). Intermediate Accounting (12th ed.). New York: Wiley \& Sons.

Kiley, M. T. (2004). Stock Price and Fundamentals: A Macroeconomic perspective. Journal of Business, 77(4), 909-936. https://doi.org/10.1086/422629

Leggio, C. Q. (2005). A Comparison Between Fama and Freuch's Model and Artificial Neural Networks in Predicting the Chinese Stock Market. Computers and Operations Research, 32, 2499-2510. https://doi.org/10.1016/j.cor.2004.03.015

Menike, P. D., \& Prabath, U. S. (2014). The Impact of Accounting Variables on Stock Price: Evidence from the Colombo Stock Exchange, Sri Lanka. International Journal of Business and Management, 9(5), 125-137. https://doi.org/10.5539/ijbm.v9n5p125

Mohammed, I. T. (2014). Analysis and discussion of liquidity and returns of ordinary shares applied study in the Iraqi market for securities. Journal of Baghdad College of Economic Sciences, 20(78).

Mohammed, I. T., \& Adnan, M. H. (2014). Liquidity of Financial Markets and Their Impact on Ordinary Share Earnings. Journal of Economic and Administrative Sciences, 20(76), 176-195.

Naimy, Y. V. (2008). Financial Ratios and Stock Prices: Consistency or Discrepancy? Longitudinal Comparison Between UAE and USA. Journal of Business \& Economics Research, 6(1), 41-50. https://doi.org/10.19030/jber.v6i1.2378

Najem, A. A. (2006). The extent to which investors in the Palestine Securities Exchange understand the importance of using accounting information to rationalize investment decisions (unpublished master thesis). Islamic University, Gaza, Palestine.

Noor, M., \& Al-nami, A. (2003). Financial \& Banking (11th ed.). Amman: Dar-almassira.

Pilbeam, K. (2007). Finance and Financial Markets (10th ed.). England: Bristol.

Sarkesian, T. A. (2010). Financial Factors Determined for Market Prices of Jordanian Joint Stock Companies listed on the Amman Stock Exchange (unpublished Master Thesis). Middle East University, Amman, Jordan.

Sharab, S. O. (2006). The effect of the announcement of the distribution of profits on the shares of companies listed on the Palestine Securities Exchange (unpublished Master thesis). Islamic University, Gaza, Palestine.

Shayeb, M., \& Ali, A. (2006). The relationship between the performance of equity investment and the ratio of market price per share to earnings per share. Journal of Jordanian Business Administration, 2(1).

Shenbagaraman, P. (2003). Do Futures and Options Trading Increase Stock Market Volatility? \{Electronic version $\}$. National stock exchange of India. Retrieved from http://www.nseindia.com

Umit, G., \& Jamal, K. H. (2002). Stability of the Policy of Dividend Distribution and the Effect of Dividends on Stock Prices. Journal of the Islamic University (Series of Humanitarian Studies), 15(2).

\section{Copyrights}

Copyright for this article is retained by the author(s), with first publication rights granted to the journal.

This is an open-access article distributed under the terms and conditions of the Creative Commons Attribution license (http://creativecommons.org/licenses/by/4.0/). 